\title{
Factors that Hinder Ndergraduate Students from Venturing into Businesses While Studying
}

\author{
Zurina Patrick ${ }^{1}$, Adriana Mohd. Rizal ${ }^{2}$, Suzilawati Kamarudin ${ }^{3}$ and Ong \\ Choon Hee ${ }^{4}$ 1,2,3,4 Azman Hashim International Business School, Universiti \\ Teknologi Malaysia, Malaysia.
}

\begin{abstract}
Although various government assistance and support are made available to aid undergraduate students to start their own business while studying, readiness among the students to engage in entrepreneurial activity is still low. It is essential to determine the factors that hinder undergraduate students from venturing into business while studying, as the future working environment largely depends on the enthusiasm, the agility, and the creativity of these generations. Studies on the factors that cause undergraduate students not to opt entrepreneurship are indeed imminent. Hence, this study is meant to enhance our understanding the link between business start-up challenges and entrepreneurship intentions in explaining why undergraduate students are more likely to seek employment, instead of generating their own income. This study utilized the case study methodology and selected several undergraduate students from a research university in Malaysia as the research setting. This study discovered five factors, including lack of family support, lack of resources, lack of social networking, fear of risk, and aversion to stress, which hinder undergraduate students from starting a business. These insights are useful for academic, entrepreneurial educators, advisors or consultants, and policymakers to enhance entrepreneurship intentions in supporting entrepreneurship activities among undergraduate students.
\end{abstract}

Keyword: Entrepreneurship intention, undergraduate students, lack of family support, lack of resources, lack of social networking, fear of risk and aversion to stress

\section{Introduction}

The entrepreneurial activities of Small and Medium Enterprises (SMEs) are important to improve the economy and the well-being of the country (Hatten, 2006; Hoelscher and Elango, 2012; Urbano and Aparicio, 2015; Malaysian SMEs, 2017). Entrepreneurship has emerged as a national agenda in many nations, including Malaysia, due to its potential in advancing both the people and the nation (Zahra and Wright, 2016). 
Small businesses are trendy in the present entrepreneurship as they contribute to employment, political, and social well-being of people, apart from promoting innovative power and competitiveness (Thurik and Wennekers, 2004). Nonetheless, limited business experience, lack of social capital, and reluctant to take risk are the major reasons these undergraduate students are unwilling to venture into business (Shandhu et al., 2011; Qunlian, 2011; Shamsuddin et al., 2017). In this line, Sharma and Madan (2013) indicated that undergraduate students are inclined towards seeking jobs after graduation.

It is critical to highlight the challenges of starting up a venture among undergraduate students to boost their entrepreneurial intentions. According to Akmaliah and Hisyamuddin (2009), Malaysian students are keen in becoming self-employed, but they lack confidence in becoming an entrepreneur. Data from the Global Entrepreneurship Monitor highlighted that self-confidence has a very high impact on the relevant skills to support one's own business (Reynolds et al., 2001; Arenius and Minniti, 2005). Additionally, based on the outcomes of different schools of thought, it is clear that selfconfidence is a construct that determines the true feelings of a student's belief in his judgment, quality, and abilities (Gelaidan and Abdullateef, 2017). In 2014, the Ministry of Education conducted a study called 'Graduate Detection

Study' and reported only $2 \%$ of graduates who ventured into business after graduation. The problem with business start-up is that it is not only about penetrating the market, but also how to survive in the market (Eftekhari and Bogers, 2015). In fact, several issues appear to either hinder undergraduate students from entering the business market or upon entering the trade arena leading to their businesses failure (Raeesi et al., 2013). Hence, in order to encourage the growth of entrepreneurs among undergraduate students, as well as to assist them to face any imminent obstacle confidently, it is important for them to sculpt a specific concept for business, knowledge regarding financial resources to start a business, and possession of funds necessary to start their own business activity (Staniewski and Szopiński, 2015).

The Government has highlighted the importance of entrepreneurship development and entrepreneurship with the establishment of the Malaysian Entrepreneurs Ministry since 1995 (Shandhu et al., 2011). Based on the Eleventh Malaysian Plan (11MP), the development of SMEs has always become a government concern (Malaysian SMEs, 2017). The Master Plan aims to boost the contribution of SMEs to the Malaysian economic by 2020 (Malaysian SMEs, 2017). The establishment of this special ministry for entrepreneurship and an agenda established in 11MP are timely to resolve the issue of changing the job landscape in Malaysia. Graduate unemployment is becoming a major problem in Malaysia and it was reported that the number of unemployed graduates was 
approximately 3.4 percent in 2017 (The Statistics Portal, 2018). This data also suggest that economic development seems to be creating an insignificant number of jobs than it used to, thus making it more difficult for people to compete for employment. The problem of graduate unemployment can be resolved if they take their own initiative to create their own income by venturing into business (Ahmad and Xavier, 2012).

Although the aspect of entrepreneur motivation has received significant research attention, studies pertaining to undergraduate students' motivation to start entrepreneurship are in scarcity. The understanding of "why undergraduate students choose not to become entrepreneurs" is under researched. Therefore, this study aims to identify the factors that deter the undergraduate students from starting a business. This research is important in the quest of developing the national economy, as the goal is to minimize the problem of graduate unemployment (Kuriakose \& Joseph, 2015). Not surprisingly, studies related to SMEs appear to mainly focus on the motivation among entrepreneurs than the obstacles faced by entrepreneurs (Ismail, et al., 2009; Yeng-Keat and Ahmad, 2012; Sivarajah and Achchuthan, 2013; Raeesi et al., 2013; Ambad \& Damit, 2016). Research on the obstacles faced by entrepreneurs, particularly on factors that hinder undergraduate students from starting a business, are important due to the fact that the future work environment largely depends on the enthusiasm, the agility, and the creativity of these generations (Kvedaraite, 2014). According to Halim et al., (2017), Malaysia is the center of attention amongst foreign investors, politicians, and researchers due to its fast-growing economy. As such, there is a need to identify the factors that impede undergraduate entrepreneurship for a healthy economic development. Understanding the challenges towards entrepreneurship will also help policymakers in designing high-impact strategies to reduce the obstacles faced by these undergraduate students in venturing into business. The present study is an effort to bridge this gap in the literature.

The paper is organized as follows. The subsequent section discusses the underpinning theories and followed by the methodology adopted in this study. Sections on case study approach, as well as results and discussion, come next. Finally, the implication, the conclusion, and future directions are highlighted.

\section{Theoretical Background}

\section{Underpinning Theories}

This study is underpinned by the psychological theory and the social networking theory. 


\section{Psychological Theory}

Researchers have concentrated on the assortment of marvels from the underpinning theory of entrepreneur's psychological aspect (Busenitz and Barney, 1997). Entrepreneurial psychology is part of entrepreneurial activity that is vital in planning procedures to decide the achievement of the association (Dess et al., 1997). The innovation and willingness to take entrepreneurship risk give entrepreneurs a competitive edge (Miller and Friesen, 1982). Miller (1983) proposed a theory of entrepreneurship action by combining the main dimensions of a firm, such as innovation, efficiency, risktaking, and proactive actions. A proactive attitude is closely related to the recovery and creation of new resources (March, 1991; Lumpkin and Dess, 2001). According to Churchill and Lewis (1986), the psychological theoretical context is used more widely to determine one's personal measure of entrepreneurial intentions (Churchill and Lewis, 1986). Another imperative variable in business activity is self-productivity, an exceedingly viable indicator of inspiration and learning for the past two decades (Zimmerman, 2000). Entrepreneurship is viewed as an element that is related to one's understanding that helps in the thinking process of taking up the challenges along with the opportunities by overcoming threats (Gerba, 2012). The concept of risk-taking is linked with the entrepreneurial process when an entrepreneur is always ready to engage in business risk after making certain arrangements (Brockhaus, 1980). This concept also means that the ventures will always be ready for business commitments to specific resources to achieve higher returns on the transactions that are yet to be identified (Brockhaus, 1980; Miller, 1983; Lumpkin and Dess, 1996).

\section{Social Networking Theory}

An assorted cluster of research customs has formed the current state of social networking theory (Liu et al., 2017). According to Grabher and König (2017), personal networks have become a more important way of entering an increasingly uncertain market for work, reputation, and information. Entrepreneurs require information, capital, skills, and labor to start business activities (Greve \& Salaff, 2003). Students of entrepreneurship increasingly recognize that entrepreneurs embed their business decisions in social structures (Larson and Starr, 1993; Borch, 1994; Hansen, 1995; Campopiano, Minola and Sainaghi, 2016). According to Nahapiet and Ghoshal (1998), entrepreneurs need to know how to manage a wide set of relationships that is beneficial to the business, such as access to resources and useful information related to the business or market. Students can gain the benefit of the existing social media platforms to build a social relationship and collect useful information. The growing use of social networking applications, such as Facebook, Blog, YouTube, Twitter, and Instagram, is embedded with external knowledge that supports entrepreneurial journey (Palacios-Marqués, 
SotoAcosta, and Merigó, 2015). In addition, new entrepreneurs are aware that generating innovative ideas cannot be accomplished without the involvement of digital tools (Dholakia and Durham, 2010; Bharati, Zhang, and Chaudhury, 2013; Scuotto, 2015; Scuotto, Ferraris, and Bresciani, 2016). That is because; entrepreneurs need to strengthen their capacity to engage external knowledge largely from the virtual setting and combine it with internal knowledge (Cohen and Levinthal, 1990).

\section{Job Seeker versus Job Creator}

Vianen (2000) suggested that certain factors, such as attitudes, personalities, abilities, values, and various dimensions of work, as well as behavioral factors with culture and organization, are the contributors on why many prefer work environment. Researchers have confirmed that intentions play an important role in the decision to start a new business (Ozaralli and Rivenburgh, 2016). Not all students view entrepreneurship as a career, as entrepreneurship may simply be viewed as the best job available at a time (Burton, Sørensen, and Dobrev, 2016). Most entrepreneurs start their own businesses after working for established firms for a few years (Beckman and Burton, 2008; Sørensen and Fassiotto, 2011). According to Olugbola (2017), there are many business opportunities out there, but only a few can identify and turn them into productive production. In precise, many students have business ideas, but only a fraction possesses the capacity and the ability to turn it into viable businesses (Shane, Locke and Collins, 2012). Other researchers believe that industry experience can also help potential entrepreneurs to carry out the proper business required to assess the merits and potential risks linked with product availability and competitiveness (Gabrielsson and Politis, 2012). Work experience offers valuable training to individuals in designing, organizing, and improving communication skills prior to their own venture (Gabrielsson and Politis, 2012). From this point of view, industry experience has the potential to provide business ideas that benefit prospective entrepreneurs. To motivate students to start their own business, they need motivation from the government, their lecturers, family, friends, and religious group (Olugbola, 2017). McClelland (1961) stated that students with higher motivation are more likely to be ready to set up their own ventures than those with low motivation to engage in activities or tasks that portray a high degree of individual responsibility or outcomes.

\section{Factors that Hinder Undergraduate Students from Starting a Business While Studying}




\section{Lack of Resources}

According to Ramayah and Harun (2005), one major drawback in starting a business is lack of capital access. When directly questioned in interviews, potential entrepreneurs claimed that raising capital seemed to be their principal problem (Blanchflower and Oswald, 1998). Ven (2007) revealed that capital, which is a critical resource that indirectly affects the form of new business, accessibility of information or user data related to industry or market, contributes to new business creation. Monetary assets empower business visionaries to support product development, deploy marketing campaigns, as well as recruit and hire capable workers (Huang and Knight, 2017). However, financial resources alone are insufficient to build a business (Huang and Knight, 2017). Access to partners and consultants or advisors as a social resource greatly helps in reinforcing business ideas (Coase, 1937; Connor and Prahalad, 1996; Grant, 1996; Kogut and Zander, 1992). Social networks are expected to influence entrepreneurial success because they give access to resources (Jenssen \& Koenig, 2002). According to Aldrich and Ruef (2006), at least half of the new efforts have fallen in five years, clearly displaying unpredictable entrepreneurial ventures. To reduce the probability of failure and succeed in launching new business, entrepreneurs must secure a diverse set of resources (Van de Ven et al., 1999).

\section{Lack of Social Networking}

Nahapiet and Ghoshal (1998) defined 'social capital' as the "sum of actual and potential resources embedded within, available through, and derived from the network of relationships possessed by individuals". In practice, developing a network that provides or facilitates access to the necessary business resources is essential to succeed and achieve the desired outcomes, often through a broker (Burt, 2005). Vissa (2012) suggested that strong social capital grows through one's network expansion behaviors that involve reaching out to new friends or contacts and establishing interpersonal knowledge of them. Entrepreneurs have the greater part of the assets and abilities they have to make and develop their ventures (Granovetter, 1995). Many researchers believed that to access financial and other resources, entrepreneurs often rely on personal social networks to facilitate their activities (Granovetter, 1985; Granovetter, 1995; Jack and Anderson, 2002; Greve and Salaff, 2003). In particular, social networking is comprised of innovative cross organizations that work together on the dual mission of financial sustainability and social purpose (Doherty, Haugh, and Lyon, 2014). Another innovative research carried out by Sandhu et al. (2011) revealed that social and organizational networks are essential 
for new start-ups. Social networking is an integral part of the social capital of entrepreneurs and also serves to increase human capital returns, such as intellect and education (Burt, 1997). Human and social capitals seem to have an impact on small business performance (Sandhu et al., 2011). Sandhu et al. (2011) revealed that social networking in Malaysia is an important factor in influencing SMEs activities, and such lack of social networking can hinder entrepreneurship intentions.

\section{Fear of Risk}

Prior studies have demonstrated that risk construct in literature on entrepreneurship and risk-taking capabilities is a key feature of entrepreneurs (Van and Cramer, 2001; Hvide and Panos, 2014; Hamböck et al., 2017). One who starts a business serves both self-interest and aggregate interest by addressing unmet social and ecological needs, which are generally referred to as sustainable entrepreneurs (Hoogendoorn, Zwan, and Thurik, 2017). An innovative research conducted by Wang and Wong (2004) found that fear of risk was a factor that affected entrepreneurial intention. Additionally, researchers have argued that different types of entrepreneurs face different types of risks (Shaw and Carter, 2007; Block et al., 2015). For instance, Shaw and Carter (2007) suggested that social entrepreneurs fear personal risks of a non-financial type, such as the risk of losing local credibility or their network of personal relationships. According to Hofstede (1980), the society in Malaysia is perceived as having a high level of uncertainty avoidance. As a result, it can be assumed that Malaysians are risk-averse, especially when it comes to entrepreneurship (Hofstede and Bond, 1988).

\section{Aversion to Stress}

It is obvious that the process of entrepreneurship initiates the demand for work assignments, social obligations, and interpersonal relations (Sandhu et al., 2011). While creating and running new businesses, individuals are exposed to high levels of stress (e.g., unpredictable environments, rapid change, personal responsibility for others, work overload) (Baron, Franklin, and Hmieleski, 2016). The uncertain or unknown poses anxiety that puts pressure on many people; on the contrary to the universal fear caused by known or understood threats (Sandhu et al., 2011). High levels of stress may interfere with entrepreneurs' capacity to perform several tasks crucial to the success of their new ventures (Baron, Franklin, and Hmieleski, 2016). Henderson and Robertson (1999) discovered that students who did not intend to become entrepreneurs had wanted to live a family life and assume that entrepreneurship involved too much work. Since the Malaysian society has a high degree of uncertainty avoidance (Hofstede, 1980), Sandhu 
et al. (2011) assumed that Malaysians are more averse to stress, hence exerting a high degree of uncertainty avoidance.

\section{Research Methodology}

This study employed the explanatory case study methodology to determine the factors that hindered undergraduate students from venturing into business while studying. Following the eight steps in the theory development process (Eisenhardt, 1989; Yin, 2009), this study sought to answer the following research question; "what factors hinder undergraduate students from starting a business and why they choose not to become entrepreneurs?" The case study protocol integrated in-depth interview sessions with four undergraduate students from a research university in Malaysia to gather all relevant information. The case was developed in a chronological format and analytic generalization was established. The identification of variables that functioned as the obstacles to entrepreneurs was also recognized. Finally, the model and the construct development were iterative, while comparison between the findings of the study and literature was necessary to establish internal validity.

\section{Case Study}

\section{Case 1}

Case 1 was from Pontian, Johor and she studied marketing at the research university. Previously, Case 1 attended Perlis Matriculation College (PMC). She was raised in a family of entrepreneurs. Her mother was a tailor. She loved to help her mother since she was twelve years old. Her duties were to accept and record orders from customers. Case 1 was actively involved in entrepreneurial activities at her college, especially during entrepreneurship carnival. In her first semester at the university, she joined the Ice Festival program 2014, organized by her faculty. She was also involved in Valet Breakfast and Marketing Symposium programs during her second semester at the university. She said that all the entrepreneurial programs enhanced her knowledge and entrepreneurship skills.

Case 1 business dream was to open a library café for the young generation, where they could enjoy some cakes and soft drinks while studying. However, Case 1 claimed that her dream would only be realized after working for a few years. She foresaw high investment in establishing a good library café with enough resources for books, magazine collections, comfortable tables and chairs, as well as the facilities. Case 1 stated that she lacked the confidence to start a business while studying due to limited capital and unready to face risks in business. She believed that the most difficult aspects were to gain adequate 
money to start and sustain the business. She was worried that she might fail her studies and that would generate a lot of stress. She also thought that business experience was very important to have better understanding of the business structure. Besides, her family advised her to focus on her study as she was awarded with a scholarship by the Public Service Department.

\section{Case 2}

Case 2 was a part-time student who studied at a research university while working for an advertising company at the southern part of peninsular Malaysia. She was born in a successful entrepreneur family in Sarawak. Her father was one of the major oils and gas entrepreneurs. Since young, she was exposed to entrepreneurial activities as most of her family members had their own businesses. For example, her brother owned a car repair shop, her sister and aunts sold boutique clothing, and her uncles ran conglomerates in Sarawak. In 2014, together with friends, she set up a food kiosk to sell various types of dishes at a three-day entrepreneurial week in their college.

She had joined a few entrepreneurship programs organized by the entrepreneurship unit of the university. The entrepreneurship programs had many activities, such as team building programs, business proposal competitions, business talks by experts, and training sessions by industry expertise. Although she could secure financial assistance from her family to start a business, she preferred using her own money to get her own resources and build her own company with her own efforts. However, she realized that to do that was not easy. She would also need a good business plan and ready to face all the challenges in the business, including failure.

\section{Case 3}

Case 3 was from Terengganu and she studied marketing at the research university. Previously, Case 3 studied at PMC. She had no entrepreneurial background. Her family also did not venture into business. During her matriculation study, she had only involved in a business carnival because it was a compulsory program for students. She did not have any interest in business. Case 3 revealed that she did not join any entrepreneurship program in the university, except taking an entrepreneurial subject in her second year at the university.

Surprisingly, she ran a Polaroid business and had registered her business under the Companies Commission of Malaysia. She used her monthly allowance given by her parents to establish the Polaroid business. She did not want to apply any loan from the bank because her business required a small amount of investment and she already had her own printer to print photos. Even though the business was not really profitable, and the 
revenue was not really big, she said the experience was worthwhile because of her interest in printing. She believed that her involvement in the printing business helped her to reduce life pressure. One of her business strategies was to gain as many followers as possible from her Instagram account. Case 3 also had good relationship with the director of the GIS 2.0 Program that provided her with a place to open her Polaroid booth in March 2018. Even though she was passionate of her business, she chose to work in the field of technology after her graduation. She wanted to gain as much experience from working with people before creating jobs for herself and others.

\section{Case 4}

Case 4 originated from Banyuwangi, Jawa Timur, Indonesia. Her parents moved to Selangor, Malaysia when she was a child. She was an accounting student at a research university. Previously, she studied at the PMC. Her family ran a restaurant in Selangor. She often helped her family around the restaurant. Her first brother and second sister were forced to quit schooling as they did not have enough money. She was the only one who had managed to further her studies to tertiary level. She took an entrepreneurial subject in the second semester at the university, but it only covered basic knowledge of entrepreneurship and business practices. In addition, she never joined any entrepreneurship program and was clueless about entrepreneurship activities held by the entrepreneurship unit at the university.

Case 4 aspired to become a successful accountant or hoped to work with Lembaga Hasil Dalam Negeri (LHDN). According to her, it is important to work and gain as much experience as she could as it was not easy to start a business or create jobs for others. She said that in order to be a successful entrepreneur or businesswoman, she must be ready to hold the responsibility to run a business. She admitted that risk and lack of resources were the main reasons on why she was afraid to start her own business.

Case 4 had not experienced establishing any business yet. At present, she helped her friends to sell and deliver coffee to customers. She observed that the business was not profitable and thought about quitting the job. Instead, she wanted to focus on maintaining her good grades every semester so that she could get first class degree in her study. She believed that running a business and studying at the same time could be tiring.

\section{Results and Discussion}

The findings showed that lack of resources and social networking, fear of risk, and aversion to stress hindered the undergraduate students from starting a business while 
studying. In addition, the study found that lack of family support also hindered undergraduate students from establishing new ventures in university.

\section{Lack of Resources}

All cases agreed that business resources are essential to establish new ventures. Capital, social resources, personal skills, and talents are vital to start up a business. Three cases had limited resources to start business while studying, especially money capital. Additionally, Cases 1, 2, and 4 admitted that they had the intention to start their own business. Case 1 had wanted to run a library café, but she had limited resources to cover all expenses, such as rental fee and utilities, shop design charge, facilities, labor wages, foods, and drinks. Case 2 dreamt of opening a Website Analytical Consultant Service, however, claimed that her skills and talent in this field were insufficient. Working with a technology company would enhance her experience and skills. Case 4 said that she did not have any financial support and preferred to start her career in the government sector. Case 3 had registered a business with Companies Commission of Malaysia after the government has launched free business registration for university students. She had the equipment to start her Polaroid business and had no problem running her business.

\section{Lack of Social Networking}

Social networking seemed to influence entrepreneurial success as the subjects had access to resources (Jenssen \& Koenig, 2002). Personal social networking (e.g. family and friends) is crucial amongst undergraduate students to facilitate their entrepreneurship activities (Granovetter, 1985; Granovetter, 1995; Jack and Anderson, 2002; Greve and Salaff, 2003). As social resources greatly assist in reinforcing business ideas (Coase, 1937; Connor and Prahalad, 1996; Grant, 1996; Kogut and Zander, 1992), they need advisors who can offer financial and non-financial support to enhance their personal confidence. Cases 1, 2, and 4 did not have support from their families or friends. Meanwhile, Case 3 had support from her family and friends. In Case 3, her parents always supported her to be more confident and gave her the capital to purchase a printer machine for her business. Case 3 also established networks from her online followers throughout Malaysia.

\section{Fear of Risk}

All cases were aware of business risk. All cases stated that they were afraid of losing focus on their studies. Cases 1, 2, and 3 asserted that they were worried if they failed in their studies due to time constraint (too much focus placed on business) or upon launching their businesses, they may fail due to poor response. Although Case 3 ran her own 
business while studying, she stated that her Polaroid business was just for fun and she was not going to give her full commitment to her business. Furthermore, she was not going to proceed with the business after graduation.

Even though the entrepreneurship unit in the research university offered financial aid for students to start their businesses, all students in the cases refused to take the risk of borrowing to avoid having problems in their final semester. Besides, they preferred not to take personal loans at a young age to avoid bankruptcy.

\section{Aversion to Stress}

1,2 , and 4 stated that they had personal commitments towards their studies and family. They felt that they did not have much confidence to start a business while studying due to many assignments and exams pressure. As for Case 3, she enjoyed doing her business and it only took two hours per day to print the pictures for her customers. However, she faced problems when the printer broke down and had to refund all the money.

\section{Lack of Family Support}

Cases 1,2, and 3 stated that their parents did not allow them to start business while studying. All the three cases were not from rich families. They received scholarships from the Malaysian government. As a result, they had to maintain excellent results to secure their scholarship. Moreover, they held on their parents' expectations and advise to give full commitment towards their studies and to focus on establishing new firms only after they have completed their studies. However, Case 3 received full support from her parents when they gave her encouragement and financial support to start her business while studying.

\section{Study Implications}

This study offers a few recommendations for policymakers and universities. First, the existing policies should be improvised to fit the needs of undergraduate students with a focus on financial support, as well as entrepreneurship programs at university levels. Second, universities should conduct various entrepreneurship programs. Local universities should always update information on financial and non-financial support provided by the government to undergraduate students as some of them may be unaware of the latest updates. This can be performed by inviting government agencies and successful entrepreneurs to give talks to the students. The universities need to alert the 
students on the availability of various support systems offered by the government agencies, such as the Ministry of International Trade and Industry (MITI), Ministry of Finance (MoF), Majlis Amanah Rakyat (MARA), and Tabung Ekonomi Kumpulan Usahawan Niaga (TEKUN).

The government agencies need to collaborate with local universities to determine the types of entrepreneurship-related trainings that are necessary for undergraduate students to enhance their skills in running their own businesses while studying. This is important to balance their studies and time taken to participate in the training events. One effective way to motivate students in starting their business while studying is by maintaining the free business registration at Companies Commission of Malaysia for both full-time and part-time students. This effort can help to increase the number of young entrepreneurs that contribute to the development of Malaysian economy, as well as to overcome the issue of unemployment among graduates.

\section{Conclusion And Future Research Direction}

This study broadens the understanding of factors that hinder undergraduate students from starting a business while studying. These factors include lack of resources, lack of social networking, fear of risk, aversion to stress, and lack of family support. Further researches should investigate the role of family support within the context of new venture creation, venture growth, and venture success either by offering access to resources and information (i.e., the family support perspective) or by interfering with work (i.e., the work-family conflict perspective). Examining these contexts is bound to expand the primary view of family role in the organizing theory literature. Additionally, it would be interesting to focus on undergraduate students who have ventured into business and compare those successful with the unsuccessful ones.

\section{Acknowledgment}

The study was supported by Universiti Teknologi Malaysia and Malaysian Ministry of Higher Education under Fundamental Research Grant Scheme (FRGS), No.:R.K130000.7863.4F858, entitled - A Framework for Exploration and Exploitation Strategies in Family Firm.

\section{References}

Ahlstrom, D. and Bruton, G.D. (2002). An institutional perspective on the role of culture in shaping strategic actions by technology focused entrepreneurial firms in China. Entrepreneurship Theory and Practice, 26(4), pp. 53-69. 
Ahmad, S. Z., and Xavier, S. R. (2012). Entrepreneurial environments and growth: Evidence from Malaysia GEM data. Journal of Chinese Entrepreneurship, 4(1), pp. 50-69.

Akmaliah, Z.P. and Hisyamuddin, H. (2009). Choice of self employment intentions among secondary school students. The Journal of International Social Research, 2(9), pp. 540-549.

Aldrich, H. E., and Ruef, M. (2006). Organizations evolving. London: Sage Publication Inc.

Ambad, S. N., \& Damit, D. H. (2016). Determinants of Entrepreneurial Intention among Undergraduate Students in Malaysia. Procedia Economics and Finance, 37, pp. $108-114$.

Barley, S. R. and Tolbert, P. (1997). Institutionalization and structuration: Studying the links between action and institution. Organization Studies, 18(1), pp. 93-117.

Baron, R., Franklin, R. and Hmieleski, K. (2016). Why Entrepreneurs Often Experience Low, Not High, Levels of Stress. Journal of Management, 42(3), pp. 742-768.

Beckman, C.M., and Burton, M.D. (2008). Founding the future: Path dependence in the evolution of top management teams from founding to IPO. Organization Science, 19(1), pp. 3-24.

Bharati, P., Zhang, C., and Chaudhury, A. (2013). Social Media assimilation in firms: Investigating the roles of absorptive capacity and institutional pressures. Information Systems Frontiers. doi:10.1007/s10796-013-9433-x

Blanchflower, D.G. and Oswald, A.J. (1998). What makes an entrepreneur? Journal of Labor Economics, 16(1), pp. 26- 60.

Block, J., Sandner, P., and Spiegel, F. (2015). How do risk attitudes differ within the group of entrepreneurs? The role of motivation and procedural utility. Journal of Small Business Management, 53(1), 183-206.

Borch, O. (1994). The process of relational contracting: Developing trust-based strategic alliances among small business enterprises. In A. H. P. Shrivastava, Advances in Strategic Management (pp. pp. 113-135).

Brockhaus, R. H. (1980). Risk Taking Propensity of Entrepreneurs. Academy of Management Journal, 23(3), pp. 509-520.

Bruton, G. D., Ahlstrom, D., \& Li, H.- L. (2010). Institutional Theory and Entrepreneurship: Where Are We Now and Where Do We Need to Move in the Future? Entrepreneurship Theory and Practice, pp. 421-440.

Bruton, G.D. and Ahlstrom, D. (2003). An institutional view of China's venture capital industry: Explaining the differences between China and the West. Journal of Business Venturing, 18(2), pp. 233-260. 
Burt, R. (1997). The contingent value of social capital. Administrative Science Quarterly, 42, pp. 339- 65.

Burt, R. (2005). Brokerage and Closure: An Introduction to Social Capital. Oxford: Oxford University Press.

Burton, M., Sørensen, J. and Dobrev, S. (2016). A Careers Perspective on Entrepreneurship. Entrepreneurship Theory and Practice, 40(2), pp. 237-247.

Busenitz, L.W. and Barney, J.W. (1997). Differences between entrepreneurs and managers in large organizations: biases and heuristics in strategic decisionmaking. Journal of Business Venturing, 12(6), pp. 9-30.

Campopiano, G., Minola, T. and Sainaghi, R. (2016). Students climbing the entrepreneurial ladder. International Journal of Contemporary Hospitality Management, 28(6), pp. 1115-1136.

Chang, E., Memili, E., Chrisman, J., Kellermanns, F. and Chua, J. (2009). Family Social Capital, Venture Preparedness, and Start-Up Decisions. Family Business Review, 22(3), pp. 279-292.

Churchill, N.C. and Lewis, V.L. (1986). Entrepreneurship Research. Cambridge: MA: Ballinger.

Coase, R. (1937). The nature of the firm. Economica, 4, pp. 386-405.

Cohen, W. M., and Levinthal, D. A. (1990). Absorptive capacity: A new perspective on learning and innovation. Administrative Science Quarterly, 35(1), pp. 128-152.

Connor, K. R. and Prahalad, C. K. (1996). A resource-based theory of the firm: knowledge versus Opportunism. Organization Science, 7(5), pp. 477-501.

Dess, G. G., Lumpkin, G. T., and Covin, J. G. (1997). Entrepreneurial strategy making and firm performance: Test of contingency and configurational models. Strategic of Management Journal, 18(9), pp. 677-695.

Dholakia, U. M., and Durham, E. (2010). One café chain's Facebook experiment. Harvard Business Review, 88(33), pp. 26.

DiMaggio, P.J. and Powell, W.W. (1991). Introduction. In W.W. Powell \& P.J. DiMaggio (Eds.). In The new institutionalism in organizational analysis (pp. pp. $1-38)$.

Chicago: University of Chicago Press.

Doherty, B., Haugh, H. and Lyon, F. (2014). Social enterprises as hybrid organizations: a review and research agenda. International Journal of Management Reviews, 16, pp. 417-436. 
Eftekhari, N. and Bogers, M. (2015). Open for Entrepreneurship: How Open Innovation Can Foster New Venture Creation. Creativity and Innovation Management, 24(4), pp: 574-584.

Eisenhardt, K. M. (1989). Building Theories from Case Study Research. Academy of Management Review, 14(4), pp. 532-550.

Fang, T. (2010). Asian management research needs more self- confidence: Reflection on Hofstede (2007) and beyond. Asia Pacific Journal of Management, 27(1), pp. $155-170$.

Gabrielsson, J. and Politis, D. (2012). Work experience and the generation of new business ideas among entrepreneurs. International Journal of Entrepreneurial Behavior \& Research, 18(1), pp: 48-74.

Gelaidan, H. and Abdullateef, A. (2017). Entrepreneurial intentions of business students in Malaysia. Journal of Small Business and Enterprise Development, 24(1), pp. 54-67.

Gerba, D. (2012). The context of entrepreneurship education in Ethiopian universities. Management Research Review, 35(3/4), pp. 225-44.

Malaysia (2017). Government of malaysia sustainable Development Goals voluntary national review 2017 Malaysia. Putrajaya, Malaysia: Economic Planning Unit. Retrieved from https://sustainabledevelopment.un.org/content/documents/15881Malaysia.pd f

Grabher, G. and König, J. (2017). Performing Network Theory? Reflexive Relationship Management on Social Network Sites. In Networked Governance. Chambridge: Springer International Publishing.

Granovetter, M. (1985). Economic action and social structure: The problem of embeddedness. American Journal of Sociology, 91, pp. 481-510.

Granovetter, M. (1995). The economic sociology of immigration. In The economic sociology of firms and entrepreneurs. In A. Portes (Ed.) (pp. 128-165). New York: Russell Sage Foundation.

Grant, R. (1996). Toward a knowledge-based theory of the firm. Strategic Management Journal, 17, pp. 109-122.

Greve, A. and Salaff, J.W. (2003). Social networks and entrepreneurship. Entrepreneurship Theory and Practice, 28, pp. 1-22.

Gunther, I. and Launov, A. (2012). informal employment in developing countries: opportunity or last Resort? Journal of Economic Development, 97(1), pp. 88-98.

H, S.-B. (2005). Entrepreneurship and Economic Growth: An Empirical Analysis. pp. 146. Retrieved from http://degit.sam.sdu.dk/papers/degit_10/C010_031.pdf 
Halim, H. A., Hanifah, H., Ahmad, N. H., \& Ramayah, T. (2017). Chapter 4: The Impediments to Entrepreneurial Ventures among the Bottom of Piramid Community in Northern Malaysia. In Handbook of Research on Small and Medium Enterprises in Developing Countries (pp. pp. 67-81). IGI Global.

Hamböck, C., Hopp, C., Keles, C., \& Vetschera, R. (2017). Risk aversion in Entrepreneurship Panels: Measurement Problems and Alternative Explainations. Managerial and Decision Economics, 38(7), pp. 1046-1057.

Hansen, E. (1995). Entrepreneurial network and new organization growth. Entrepreneurship Theory and Practice, 19(4), pp. 7-19.

Hatten, T. (2006). Small Business Management: Entrepreneurship and Beyond, 3rd ed. New York, NY: Houghton Mifflin Company.

Henderson, R. and Robertson, M. (1999). Who wants to be an entrepreneur? Young attitudes to entrepreneurship as a career. ducation + Training, 41(5), pp. 236- 45.

Hoelscher, M. and Elango, B. (2012). The impact of business climate, foreign population and unemployment on new venture creation. Journal of Developmental Entrepreneurship, 17(4), 1250021 (14 pages).

Hofstede, G. (1980). National cultures in four dimensions: a research- based theory of cultural differences among nations. International Studies of Management and Organization, 13(1/2), pp. 46- 74.

Hofstede, G. and Bond, M.H. (1988). The Confucius connection: from cultural roots to economic growth. Organizational Dynamics, 16(4), pp. 5- 21.

Hoogendoorn, B., Zwan, P. v., \& Thurik, R. (2017). Sustainable Entrepreneurship: The Role of Perceived Barriers and Risk. Journal of Business Ethics, pp. 1-22.

Huang, L. and Knight, A. (2017). Resources and Relationships in Entrepreneurship: An Exchange Theory of the Development and Effects of the Entrepreneur-Investor Relationship. Academy of Management Review, 42(1), pp. 80-102.

Hvide, H. K., \& Panos, G. A. (2014). Risk tolerance and entrepreneurship. Journal of Financial Economics, 111(1), pp. 200-223.

Ismail, M., Khalid, S. A., Othman, M., Jusoff, H., Rahman, N. A., Kassim, K. M., \& Zain, R. S. (2009). Entrepreneurial Intention among Malaysian Undergraduates. International Journal of Business and Management, 4(10), pp. 54-60.

Jack, S.L. and Anderson, A.R. (2002). The effects of embeddedness on the entrepreneurial process. Journal of Business Venturing, 17, pp. 467-487. 
Jenssen, J. I., \& Koenig, H. F. (2002). The Effect of Social Networks on Resource Access and Business Start-ups. Journal European Planning Studies, 10(9), pp. 10391046.

Kogut, B. and Zander, U. (1992). Knowledge of the firm, combinative capabilities, and the replication of technology. Organization Science, 3, pp. 383-397.

Kuriakose. F and Joseph. J. (2015). Nurturing Youth Entrepreneurship to Tackle Youth Unemployment: A Case Study of Kerala. Journal of Research Innovation and Management Science, 1(1), pp. 5-11.

Kvedaraite, N. (2014). Experience of students of Lithuanian higher education institutions. Journal of Management, 19(1), pp. 1-16.

Larson, A. and Starr, J.A. (1993). A network model of organization formation. Entrepreneurship Theory and Practice, 17(2), pp. 5-15.

Liu, W., Sidhu, A., Beacom, A. and Valente, T. (2017). Social Netwoking Theory: In The International Encyclopedia of Media Effects. Hoboken, NJ, USA: John Wiley \& Sons, Inc.

Lumpkin, G, T. and Dess, G. G. (2001). Linking Two Dimesions of Entrepreneurial Orientation to Firm Performance. The Moderating Role of Environment and Industry Life Cycle. Journal of Business Venturing, 16(5), pp. 429-451.

Malaysia : Unemployment rate from 2007 to 2017. (2018). Retrieved from The Statistic Portal:

https://www.statista.com/statistics/319019/unemployment-rate-in-malaysia/

Malaysian SMEs. (2017). Retrieved September 15, 2017, from Official Website SMECORP Malaysia: http://www.smecorp.gov.my/index.php/en/policies/2015-12-21-090949/smestatistics

March, J. G. (1991). Exploration and Exploitation in Organizational Learning. Organization Science, 2(1), pp. 71-87.

McClelland, D. C. (1961). The achieving society. NJ: Van Nostrand: Princeton.

Miller D \& Friesen P. (1982). Innovation in conservative and entrepreneurial firms: Two models of strategic momentum. Strategic Management Journal, 3(1), pp. 1-25.

Miller, D. (1983). The Correlates of Entrepreneurship in Three Types of Firms. Management Science, 29(7), pp. 770-791.

Nahapiet, J. and Ghoshal, S. (1998). Social capital, intellectual capital, and the organizational advantage. Academy of Management Review, 23(2), pp. 242-266. 
Olugbola, S. (2017). Exploring entrepreneurial readiness of youth and startup success components: Entrepreneurship training as a moderator. Journal of Innovation \& Knowledge, 2(3), pp: 155-171.

Ozaralli, N, and Rivenburgh, N. (2016). Entrepreneurial intention: antecedents to entrepreneurial behavior in the U.S.A. and Turkey. Journal of Global Entrepreneurship Research, 6(1), pp. 3. doi:10.1186/s40497-016-0047-x

P. Arenius and M. Minniti. (2005). Perceptual variables and nascent entrepreneurship. Small Business Economics, 24, pp. 233-247.

P. D. Reynolds, S. M. Camp, W. D. Bygrave, E. Autio, and M. Hay. (2001). Entrepreneurship Monitor. 2001 Executive Report. Kansas MO: Kauffman Foundation.

Palacios-Marqués, D., Soto-Acosta, P., and Merigó, J. M. (2015). Online social networks as an enabler of innovation in organizations. Management Decision, 53(9), pp. 1906-1920.

Qunlian, L. (2011). The major difficulties and countermeasures of current university graduates' entrepreneurship in China. Journal of Chinese Entrepreneurship, 3, pp. 228-239. doi:http://dx.doi.org/10.1108/17561391111167000

Raeesi, R., Dastranj, M., Mohammadi, S., \& Rasouli, E. (2013). Understanding the Interactions among the Barriers to Entrepreneurship Using Interpretive Structural Modeling. International Journal of Business and Management, 8(13), pp. 56-72.

Ramayah and Harun. (2005). Entrepreneurial intention among the students of USM. International Journal of Management and Entrepreneurship, 1(1), pp. 8-20.

S. Shane, E.A. Locke and C.J. Collins. (2012). Entrepreneurial motivation. Human Resource Management Review, 13(2), pp. 257-279.

Schwarzer, R. (2014). Sel-Efficacy: Thought Control of Action. New York, USA: Taylor $\&$ Francis.

Scott, W. (1987). The Adolescence of Institutional Theory. Administrative Science Quarterly, 32(4), pp. 493-511.

Scuotto, V. (2015). Improving absorptive capacity through social media networks for firms' innovativeness. Paper presented at the 9th European Conference on Innovation and Entrepreneurship (ECIE 2014). Retrieved from http://academicconferences.org/ecie/ecie2014/ecie14-home.htm

Scuotto, V., Ferraris, A., and Bresciani, S. (2016). Internet of things: Applications and challenges in smart cities. A case study of IBM smart city projects. Business Process Management Journal, 22(2), pp. 357-367. 
Shamsuddin, S. F., Mamun, A. A., Nawi, N. B., Nasir, N. A., \& Zakaria, M. N. (2017). Factors Affecting Entrepreneurial Intention among the Malaysian Universiti Students. The Journal of Developing Areas, 51(4), pp. 423-431.

Shamsudin, S. F., Mamun, A. A., Nawi, N. B., Nasir, N. A., \& Zakaria, M. N. (2017). Factors Affecting Entrepreneurial Intention Among The Malaysian University Students. The Journal of Developing Areas, 51(4), pp: 423-431.

Shandhu, M. S., Sidique, S. F., \& Riaz, S. (2011). Entrepreneurship Barriers and Entrepreneurial Inclination among Malaysian Postgraduate Students. International Journal of Entrepreneurial Behaviour \& Research, 17(4), pp. 428-449.

Sharma, L. and Madan, P. (2013). Affect of perceived barriers to entrepreneurship on the career choice decision of students: A study of Uttarakhand state, India. Business and Economic Horizons, 9(2), pp. 23-33.

Shaw, E., and Carter, S. (2007). Social entrepreneurship: Theoretical antecedents and empirical analysis of entrepreneurial processes and outcomes. Journal of Small Business and Enterprise Development, 14(3), pp. 418-434.

Sivarajah, K. and Achchuthan , S. (2013). Entrepreneurial Intention among Undergraduates: Review of Literature. European Journal of Business and Management, 5(5), pp. 172-186.

Sørensen, J.B., and Fassiotto, M.A. (2011). Organizations as fonts of entrepreneurship. Organization Science, 22(5), pp. 1322-1331.

Staniewski, M. and Szopiński, T. (2015). Student readiness to start their own business. Economic Research, 28(1), pp: 608-619.

Thurik, A.R. and Wennekers, A.P.M. (2004). Entrepreneurship, small business and economic growth. Journal of Small Business and Enterprise Development, 11(1), pp. 140- 9.

Urbano,D., and Aparicio, S. (2015). Entrepreneurship capital types and economic growth: International evidence. Technological Forecasting and Social Change.

Van de Ven, A. H., Polley, D. E., Garud, R., and Venkataraman, S. . (1999). The innovation journey. New York: Oxford University Press.

Van Praag, C.M. and Cramer, J.S. (2001). The roots of entrepreneurship and labour demand: individual ability and low risk aversion. Economica, 68( 269), pp. 45- 62 .

Ven, S. T. (2007). Drivers of urban entrepreneurship: an integrative model. International Journal of Entrepreneurial Behavior \& Research, 13(4), pp. 235-51. 
Vianen, A. V. (2000). Person-organization fit: the match between newcomers' and recruiters' preferences for organizational cultures. Personnel Psychology, 53, pp. 113-149.

Vissa, B. (2012). Agency in action: Entrepreneurs' networking style and initiation of economic exchange. Organization Science, 23(2), pp. 492-510.

Wang, C.K. and Wong, P.K. (2004). Entrepreneurial interest of university students in Singapore. Technovation, 24, pp. 161- 72.

Yeng-Keat, O. and Ahmad, S. (2012). A Study among University Students in Business Start-Ups in Malaysia: Motivations and Obstacles to Become Entrepreneurs. International Journal of Business and Social Science, 3(19), pp. 181-192.

Yin, R. K. (2009). Case Study Research: Design and Methods, 4th ed. Thousand Oaks, California: Sage Publications, Inc.

Zahra, S. and Wright, M. (2016). Understanding the Social Role of Entrepreneurship. Journal of Management Studies, 53(4), pp: 610-629.

Zimmerman, B. (2000). Self-Efficacy: An Essential Motive to Learn. Contemporary Education Psychology, 25(1), pp. 82-91 